American Journal of Environmental Sciences 3 (4): 219-224, 2007

ISSN 1553-345X

(C) 2007 Science Publications

\title{
Vulnerability and Pollution Risks in the Alluvial Aquifer of Tebessa-Morsott
}

\author{
${ }^{1}$ S. Kachi, ${ }^{2}$ N. Kherici and ${ }^{3}$ N.Kachi \\ ${ }^{1}$ Department of Civil Engineering and Hydraulic, Faculty of Sciences, \\ University of Guelma, Algeria \\ ${ }^{2}$ Department of Hydrogeology, Faculty of Earth Sciences and Agronomy, \\ University of Badji Mokhtar, Annaba, Algeria \\ ${ }^{3}$ Department of Biology, Faculty of Sciences, University of Guelma, Algeria
}

\begin{abstract}
We studied the vulnerability and risks of pollution of the alluvial aquifer of TebessaMorsott that ranks amongst the major groundwater reservoirs of the region. The method used to asses groundwater vulnerability was the DRASTIC method, based on seven parameters that affect and control the groundwater flow: Depth to groundwater, Impact of the unsaturated zone, net recharge, aquifer media, hydraulic conductivity, soil media, topography. These parameters were obtained from data field, synthetic maps relative to the area considered and then identified within each cell after discretization of the studied area in regular square cells. For each cell, DRASTIC rating for each parameter was multiplied by the DRASTIC weight for that cell and summed to determine the DRASTIC index. A detailed vulnerability map was obtained, showing four classes of potential pollution of the aquifer. Check analysis of the quality of groundwater within these zones are carried out in order to assess the risks of contamination. Pollution by nitrates occurs especially in the wells of low depth, but also in certain drillings for drinking water, whereas bacteriological pollution is observed only in the domestic wells.
\end{abstract}

Key words: DRASTIC, Vulnerability, Pollution, Groundwater, Tebessa-Morsott, Algeria.

\section{INTRODUCTION}

Considering the strategic role of the alluvial aquifer of Tebessa-Morsott in the economic and social development of the area, it's necessary to protect the resources (sources, well, drillings, etc...) from any external pollution.

Over recent years, this aquifer has been threatened by numerous pollution sources that have been increased due to lack of environmental protection measures for water resources, in particular wasted domestic and industry water which poured in the aquifer without any previous treatment. The forecast of the potential risks rising from the natural environment is obvious especially when the surface of water does not exceed a few meters in the center of the plain. Moreover, high nitrate concentrations varying from 48 to $96 \mathrm{mg} / \mathrm{l}$ were already observed in the plain since the first analyses carried out by the hydraulic department in 1975/76.

Recently, high concentration of polluting elements (nitrate, fluorine and ammonium) was recorded. Bacteriological analyses carried out on the domestic wells and drillings showed that the top of the aquifer has a bed bacteriological quality (total coliforme and fecal coliforme) which make it unfit for consumption. So under an intensive exploitation of the aquifer, more intensive in dry period, they could contribute to the contamination of the deep aquifer.

The ground is composed by alluvia poor in organic matter so that an intensive use of pesticides to maintain the productivity of the ground is needed.

In front of this situation which evolves every day, it is necessary, and right now to take all measurements those guaranties a good quality of water for the future needs. In absence of any protection measure, the preventive approach, by the cartography of the vulnerability is undeniable. In a worry to protect the underground water sources, we present this study which treats vulnerability and risk of pollution of the alluvial aquifer of Tebessa-Morsott using the DRASTIC method.

Corresponding Author: $\quad$ S. KACHI, Department of Civil Engineering And Hydraulic, Faculty of Sciences, University of Guelma, Algeria 

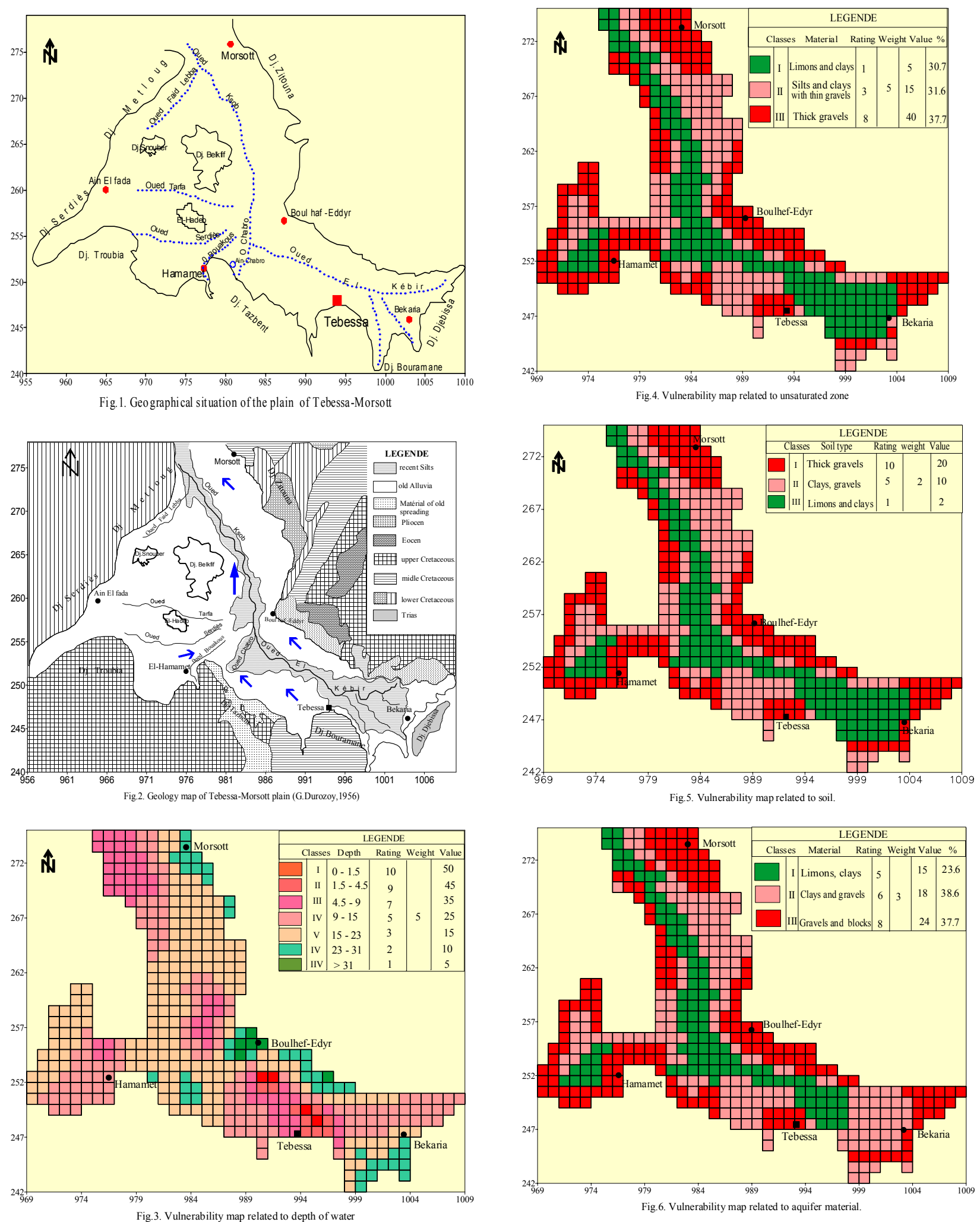

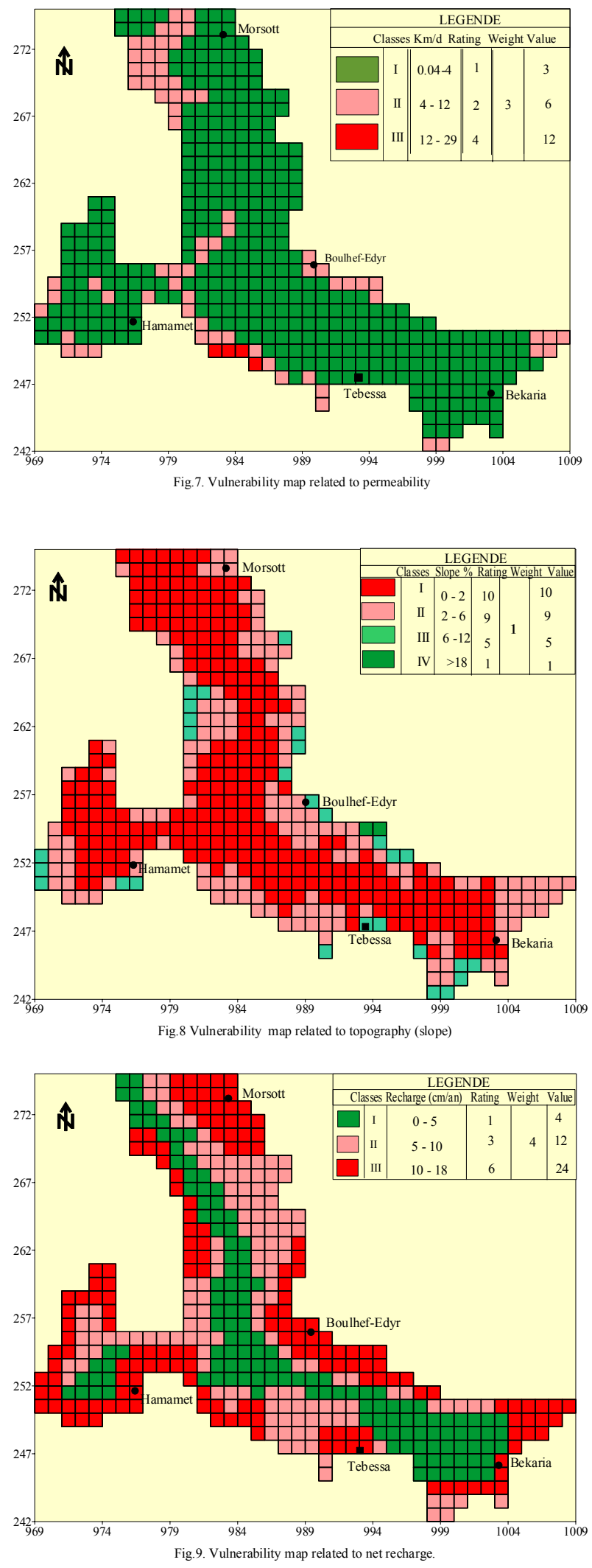

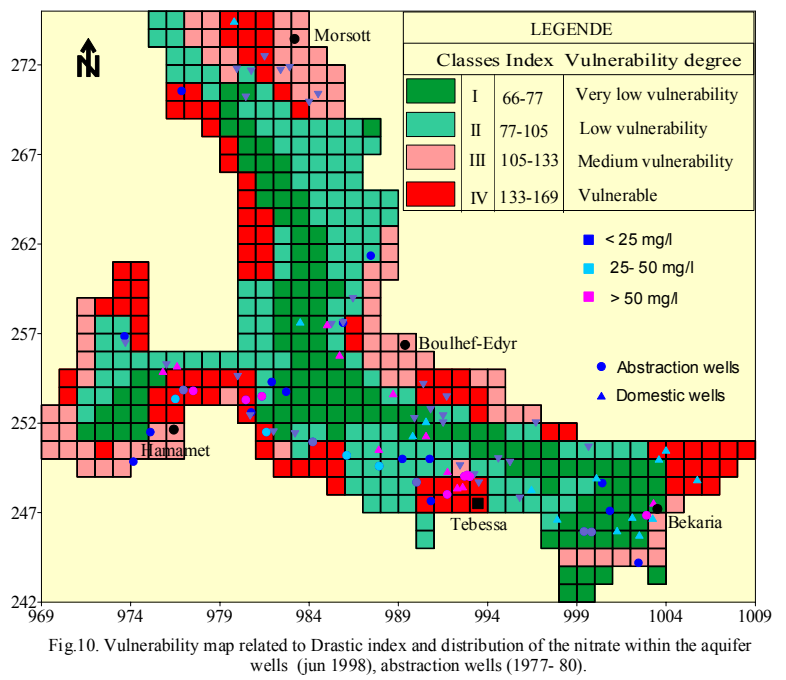

Geographical situation: The plain of TebessaMorsott corresponds to a vast closed depression of a surface of about $660 \mathrm{~km}^{2}$. It is situated to the extremity of the Algerian East to doors of the desert. It is delimited to the North by Djebel Zitouna, to the South by Djebel Tazbent, to the West by Djebel Matloug and to the East by Djebel. Djebissa and Bouramane (Fig.1)

Geology and hydrogeology: Geologically, the plain of Tebessa-Morsott corresponds to a basin of sedimentation subsiding moderately ${ }^{[4-5]}$. It is a tectonic origin pit that is formed during the tertiary and the quaternary in which detritus formations of mio-plio-quaternary are accumulated that based on a marly substratum to the center of the plain and on limestone of the Cretaceous to the edges.

The geometry of the mio-plio-quaternary reservoir depends on the nature of sediment deposits that passes $500 \mathrm{~m}$ of thickness in the center of the plain ${ }^{[8]}$ and $5 \mathrm{~km}$ of depth ${ }^{[12]}$.

The organization of these deposits in sedimentary sequence, favored the existence of the preferential horizons of water flow, characterized by an extreme lateral and vertical heterogeneity. This unconfined aquifer system to semi-confined behaviors like one hydrogeologic unit. The river Ksob drains all domestic and industrial waters that cross this plain. The groundwater flows within a direction oriented SW toward NE (Fig.2).

Drastic method: The Drastic method is one of methods of the PCSM subgroup (Point Count 
System Model) that was developed by Aller and al ${ }^{[1]}$ in the objective to value risks of underground water pollution ${ }^{[9-11]}$. It is based on the evaluation of the most physical factors that control the groundwater pollution potential such as: Depth to water (D), net recharge (R), aquifer material (A), soil type (S), topography (T), impact of the unsaturated zone (I) and hydraulic conductivity (C), in short DRASTIC. As a consequence, a numerical ranking system to assess groundwater pollution potential in hydrogeology setting has been devised [1]. The system contains three significant parts: weights, ranges and ratings.

Weights: Each DRASTIC factor had been evaluated with respect to the others to determine its relative importance and had been assigned a relative weight ranging from 1 to 5 . The weight value 5 is given to the most significant factors and the value 1 to the least significant factor.

Ranges: Each DRASTIC factor had been evaluated divided into either ranges or significant media type affect pollution. The media types are aquifer media, soil media and impact of the vadose zone media, which can't numerically measured.

Ratings: Each range for each DRASTIC factor has been evaluated with respect to the others to determine its relative significance to pollution and has been assigned a rating between 1 and 10. The DRASTIC Index can be calculated by the following equation.

$$
\begin{gathered}
\text { DRASTIC index }=\text { Dn Pp }+ \text { RnRp }+ \text { AnAp }+ \text { SnSp } \\
+ \text { Tn Tp }+ \text { In Ip }+ \text { CnCp }
\end{gathered}
$$

Where footnotes $\mathrm{n}=$ rating and $\mathrm{p}=$ weight. Once $\mathrm{a}$ DRASTIC Index has been calculated, it is possible to identify which areas are more likely to be susceptible to groundwater contamination relative to the other. The higher DRASTIC Index indicates the greater pollution potential of groundwater.

Collect of data: The parameters used by the DRASTIC method have been collected by measure on the field either provided by organisms concerned such as DHWT (Hydraulic Direction of the wilaya of Tebessa), and direction of agriculture of Tebessa.

Topographic map to $1 / 50000$ of Tebessa $\left(\mathrm{N}^{\circ} 206-\right.$ B10-C31), El -Hamamet ( $\left.\mathrm{N}^{\circ} 205-\mathrm{B} 10-\mathrm{C} 30\right)$, Morsott $\left(\mathrm{N}^{\circ} 178-\mathrm{B} 9-\mathrm{C} 31\right)$ and Meskiana ( $\left.{ }^{\circ} 177-\mathrm{B} 9-\mathrm{C} 30\right)$,

Pedologic map to $1 / 50000$ of the plain of TebessaMorsott ${ }^{[2]}$,

Piezometric map and depth of water from measures of 100 wells (April, 2002),

Hydraulic conductivity map deduced form the transmissivity values of 28 wells.

Stratigraphic log of the 28 pumping wells and the geophysical survey ${ }^{[8]}$ data are used to identify the aquifer material of the saturated and unsaturated zone.

Rainfall data recorded at the meteorological station of Tebessa within a period of 25 years (1972/73-1996/97) permitted to establish the hydrologic balance according to the method of Thornthwaite and to estimate the efficient infiltration by the equation:

$$
\mathrm{Ie}=\mathrm{P}-\mathrm{ETR}-\mathrm{R}
$$

where Ie $=$ efficient infiltration,

$\mathrm{P}=$ total precipitation,

$\mathrm{ETR}=$ real evapo-transpiration

$\mathrm{R}=$ surface flow.

Elaboration of the thematic maps of the seven parameters and discussions: The reliability of the DRASTIC method is based on a detailed characterization of the hydrogeologic units of the study area and to the exactitude of the used parameters. In this analytical mind, we discretized the field of study in 440 square and regular cells of $1 \mathrm{~km}^{2}$ of surface, in other words in 440 hydrogeologic sub-unit. After simulation by mathematical model, we know better the space distribution of certain parameters like: depth of water, permeability and net recharge.

Each parameter considered by the DRASTIC method is determined within each cell and a relative index DRASTIC is obtained by multiplying its range by its relative weight. The DRASTIC index is calculated in each cell by making the sum of these parametric indices. Thus, a vulnerability DRASTIC map is established. The calculated DRASTIC index informs us about the vulnerability degree of each cell within the aquifer

Map of water depth: In the plain of TebessaMorsott, the water depth varies from borders to the center (Fig.3). It is closer to the ground surface in the center of the plain (less than $5 \mathrm{~m}$ of depth) and deeper on the edges (more $25 \mathrm{~m}$ of depth).

Map of material of the unsaturated zone: The geophysical study ${ }^{[8]}$ as well as the stratigraphic logs of drillings put in evidence a lateral granoordering of sediments from borders towards the center of the plain: coarse texture (blocks of different sizes) close to borders and fine 
(argillaceous silts with thin gravels) in the center of the plain (Fig. 4).

Map of soil type: The pedological study of the ground of the plain of Tebessa-Morsott ${ }^{[2]}$ revealed three textures: silty-argillaceous, clay-gravel and gravelly. From the point of view of the vulnerability, gravelly texture presents the greatest risk to surface pollution and covers $37.5 \%$ of total surface. Textures clay-gravel and silty-argillacous are less vulnerable to pollution and respectively cover $31.5 \%$ and $31 \%$ of the total surface (Fig.5).

Map of aquifer material: The geo-electric profiles and stratigraphic logs of drillings permitted to distinguish three zones with a different degree of vulnerability (Fig.6).

ZoneI: Vulnerable, characterized by the predominance of argillaceous silts, sometimes intercalations of gravels or sands;

ZoneII: Less vulnerable, characterized by clays with gravels with moderate permeability;

ZoneIII: More vulnerable, characterized by thick gravels (limestone rollers), high permeability.

Map of the hydraulic conductivity: The hydraulic conductivity is calculated from the pumping test data of 28 wells and improved after calibration of the mathematical model in steady sate and varies from 4.7 $10^{-8}$ to $4.110^{-4} \mathrm{~m} / \mathrm{s}$ with an average of $2.2010^{-5} \mathrm{~m} / \mathrm{s}$ (Fig.7).

Map of slopes: One of the morphological particular of the plain of Tebessa-Morsott is in its plane topography. The slope exceeds $18 \%$ to borders and raging between 0 to $2 \%$ to the center of the plain. It is noted that $80 \%$ of total surface present a very weak slope from 0 to $6 \%$ that favorites the migration of the pollutant towards the aquifer. The least vulnerable zones are located to borders (Fig.8).

Map of net recharge: The recharge of the aquifer comes mainly from direct infiltration of water precipitation through the coarse sediments of borders and from water surface flow or flooding through river bed (mainly Bouakous river). The in flow coming from the infiltration of waters precipitation, it is very weak and does not exceed $170 \mathrm{~mm} / \mathrm{an}$, which lets admit other sources of feedings, in particular through borders (Maestrichtien limestone's). The recharge is null in the center of the plain (fine texture: silty-argillaceous) and maximal on the edges (coarse texture: blocks of various sizes) (Fig.9).
Map of groundwater vulnerability: The DRASTIC Indexes (Id) calculated within each cell vary from 66 to 169 permitted to produce a vulnerability map of the alluvial aquifer of Tebessa-Morsott (Fig.10).

In this map, we distinguish four classes with different degrees of vulnerability:

Class (I): very weak vulnerability $(66>\mathrm{Id}<77)$; Class (II): weak vulnerability $(77>$ Id $<105)$;

Class (III): moderate vulnerability (105 > Id $<133$ );

Class (IV): high vulnerability $(133>$ Id $<169)$

These classes can be gathered in two main zones.

A zone of weak to very weak vulnerability occupy respectively $35 \%$ and of $25 \%$ of the total surface. It is located in the center of the plain and along chabro-ksob river. This zone is influenced by the agricultural activities and wasted domestic and industry water.

A zone of moderate to high vulnerability extends over $15 \%$ and $25 \%$ of the total surface and occurs at the edges, in particular within different urban zones (Tebessa city, El-Hamamet, Morsott and Boulhef-edyr). In these zones, the Tebessa National Office for drinking water has many drillings, which provide more than $70 \%$ of the total drinking water needs. These zones and right now must be subjected to a rigorous control to define the adequate protection measures.

In general, a reduction of the vulnerability degree in the center of the aquifer is related to silty-argillaceous sediments and to the null recharge. The increase of the vulnerability degree to borders of the aquifer is related much more to the type of soil and aquifer material which are very permeable.

\section{CONCLUSION}

The paper presents a first application of the DRASTIC method in the alluvial aquifer of Tebessa-Morsott based on the principle of the discretization of the aquifer that led to the establishment of a detailed vulnerability map.

The map shows zones of high degrees of vulnerability noted at the edge of the study area.

The pollutants recorded within these zones valid the DRASTIC vulnerability map so they 
must be subjected to rigorous control to define and carry out the adequate protection measures.

The vulnerability map established will not be only useful to identify and delimit zones of high risk of contamination but also for the preliminary exam of the new projects with environmental incidence.

In the future we wish that the vulnerability methods that usually used will be presented in the form of software in order to facilitate calculation of the used parameters and to make them compared.

\section{REFERENCES}

1. L, Truman B., Lehr J.H., Rebcca J.P. 1985 DRASTIC: A standardized system for evaluating pollution potential using Hydrogeologic Settings, EPA, 600/2/85/018, $227 \mathrm{p}$.

2. Rapport Cabinet Lepetit 1974- Etude de la mise en valeur de la plaine de Tebessa et de la vallée de l'oued Ksob, 45 p.

3. Champagne L.R, Chapuis P. 1993- Evaluation de la vulnérabilité à la pollution des formations aquifères de la MRC de MONTCALM selon la méthode DRASTIC. Rev.Sc. de Tech de l'eau.Vol.26 (3).

4. Dubourdieu G, Durozoy G. 1950 - Observations tectoniques dans les environs de Tebessa et d'Ouenza (Algérie). Bull. S.G.F., Paris, (5), XX, 9, p.257-266.

5. Kowalski W.M et al, 1997- Les stades d'effondrements du graben de Tebessa (Confins Algéro- Tunisiens) et la tectonique plicative Plioquaternaire. Bull.Soc.Hist.Nat. Pays de Montbéliard.

6. Lyakhloufi S, Er-RouaneS, Ouazzani N, El Hebil A. Vulnérabilité et risque de pollution de la nappe phréatique du Haouz de Marrakech (Maroc). Hydrogéologie, $\mathrm{N}^{\circ} 3$, 1999, pp. 43-52, 9 fig.
7. Menani M.R 2001. Évaluation et cartographie de la vulnérabilité à la pollution de l'aquifère alluvionnaire de la plaine d'El Madher, Nord-Est algérien, selon la méthode DRASTIC.Science et changements planétaires / Sécheresse. Vol. 12, Numéro 2, Juin 2001 : 95-101, Notes originales

8. Strojexport, prospection géophysique par la méthode électrique dans la plaine de Tebessa, Prague, 1978.Opération $N^{\circ}$ 5.391.1.129.00.01

9. Suais M.F., Dubar C. 1993. Carte de vulnérabilité des eaux souterraines à la pollution et du risque de propagation de la pollution dans les nappes. Feuille de Lyon 1/50000. Actualisation des données et cartographies multicritères. Rapport BRGM R37 929 SGR 94, Décembre 1993.

10. Surfer 1996 Surface mapping.

11. system.Version 6.04. Scientific Software Inc.

12. Vrba \& Zaporozec, Ed.1995. Guidebook on mapping groundwater vulnerability. IAH, Int. Contrib.to hydrogeol., 19 1994, Heise, Hannover, 131p

13. Zerdazi A. 1990. Etude gravimétrique du mole d'Ain M'lila et de L'Atlas Saharien septentrional oriental (NE de l'Algérie). Thèse de Doctorat es Sciences. Univ.de Lausanne, $227 \mathrm{p}$.

14. Zabet T.Al,. 2002- Evaluation of aquifer vulnerability to contamination potential using the DRASTIC method. Env. Geol (2002) 43: 203-208, DOI: 10.1007/s00254-002-0645-5 